\title{
PENGARUH PENAMBAHAN HIGH FRUCTOSE SYRUP (HFS-55) TERHADAP KARAKTERISTIK RED WINE KELOPAK BUNGA ROSELA (Hibiscus sabdariffa L.)
}

\section{Effect of High Fructose Syrup (HFS-55) Addition on Characteristics of Roselle Petals Red Wine (Hibiscus sabdariffa L.).}

\author{
Anastasia Laksmi Pratiwi ${ }^{1)}$, Agus Selamet Duniaji ${ }^{2)}$, I Wayan Rai Widarta ${ }^{2)}$ \\ ${ }^{1}$ Mahasiswa Program Studi Ilmu dan Teknologi Pangan, Fakultas Teknologi Pertanian, Universitas Udayana \\ ${ }^{2}$ Dosen Program Studi Ilmu dan Teknologi Pangan, Fakultas Teknologi Pertanian, Universitas Udayana \\ Kampus Bukit Jimbaran, Badung-Bali
}

\begin{abstract}
This research was aimed to determine the effect of adding high fructose syrup (HFS-55) to red wine made from roselle flower petals that can produce roselle red wine with the best characteristics. This study used a Completely Randomized Design (RAL) with a treatment of adding HFS-55 10\%, 15\%, 20\%, 25\%, 30\%. This treatment was repeated 3 times, resulting in 15 experimental units. The data were analyzed by ANOVA and followed by Duncan test. The results showed that the adding of HFS-55 on roselle red wine has a significant effect on ethanol content, $\mathrm{pH}$, total soluble solid, total reducing sugar, aroma, taste and overall acceptance with the best treatment was obtained from the addition of $25 \%$ HFS-55 with roselle red wine characteristics containing $10.65 \%$ ethanol content, $\mathrm{pH} 3.6$, total soluble solids $10.10 \%$ Brix, total reducing sugar $10.37 \%$, total phenolic $3.08 \mathrm{mg} / \mathrm{ml}$ and total methanol was not found, and with the panelist preference for color usual, aroma rather like, taste rather like and overall acceptance rather like.
\end{abstract}

Keyword: roselle, $H F S-55$, red wine

\section{PENDAHULUAN}

Indonesia merupakan negara yang memiliki tingkat biodiversitas yang tinggi, sehingga terdapat banyak sekali tanaman yang memiliki potensi tinggi untuk dapat dimanfaatkan (Supriatna, 2008) Tanaman rosela (Hibiscus sabdariffa L.) merupakan salah satu tanaman yang dapat dimanfaatkan sebagai pangan fungsional. Tanaman rosela mempunyai habitat asli di daerah yang terbentang dari India hingga Malaysia. Sekarang, tanaman ini tersebar luas di daerah tropis dan mempunyai nama umum yang berbeda-beda di berbagai negara (Maryani dan Kristiana, 2008).

Tanaman rosela mudah dan murah jika ingin dibudidayakan karena umur panennya singkat. Tingkat konsumsi rosela terbilang masih rendah karena selama ini tanaman rosela hanya dimanfaatkan sebagai minuman kesehatan (Mardhiah dan Sulaeman, 2010). Bagian tanaman rosela yang bisa diproses menjadi produk pangan adalah kelopak bunganya. Kelopak bunga rosela memiliki pigmen antosianin yang berbentuk flavonoid yang berperan sebagai antioksidan, dimana pigmen ini membentuk warna ungu kemerahan yang menarik (Daryanto, 2008). Kandungan lain seperti asam-asam organik (malat, tartarat, dan sitrat) dan mineral juga terkandung dalam kelopak bunga rosela (Odilora et al., 2001).

Minuman beralkohol anggur atau wine merupakan minuman hasil dari fermentasi buah anggur (Vitis vinifera). Salah satu jenis varian wine adalah red wine (anggur merah). Red Wine adalah salah satu varian minuman wine yang mengandung alkohol $8-15 \%$ dan dibuat dengan cara fermentasi dari biji, kulit dan daging buah anggur (must) (Grainger dan Hazel, 2005). Varietas anggur yang biasa digunakan dalam pembuatan red wine adalah Pinot Noir, Zinfandel, Syrah, Cabernet Sauvignon, dimana di Indonesia relatif mahal karena diperlukan impor buah anggur dari luar negeri (Handoyo, 2007). Kandungan antosianin yang memiliki pigmen warna ungu kemerahan serta mineral dan asamasam organik pada kelopak bunga rosela dapat menjadi alternatif dalam pembuatan red wine Menurut Alobo dan Offonry (2009), masalah utama menggunakan bahan tanaman tropis dalam pembuatan wine adalah rendahnya kadar gula $d$

\footnotetext{
*Korespondensi Penulis:

E-mail: alaksmipratiwi@gmail.com ${ }^{1)}$
} 
tinggi tingkat keasaman, dimana kandungan gula dalam kelopak bunga rosela yang relatif rendah yakni 1,06 gram dalam 100 gram kelopak bunga rosela (Maryani dan Kristiana, 2005). Penambahan gula sebagai modifikasi dalam pembuatan wine akan mempengaruhi kualitas red wine menggunakan ekstrak kelopak bunga rosela karena merupakan sumber nutrisi utama bagi pertumbuhan pertumbuhan sel khamir, sedangkan sisanya akan dikonversi menjadi produk metabolit seperti alkohol (Azizah et al., 2012).

Judoamidjojo et al., (1992) melaporkan gula yang umum digunakan dalam pembuatan wine adalah gula pasir yang mengandung disakarida sukrosa dan akan dipecah menjadi bentuk lebih sederhana yakni glukosa dan fruktosa. Salah satu sumber gula yang lebih sederhana adalah high fructose syrup (HFS). Fruktosa biasa dikenal dengan gula buah karena dapat memberikan cita rasa buah, maka itu sering digunakan dalam industri minuman (Jaya, 2015). Fruktosa merupakan monosakarida yang pada proses fermentasi akan langsung diubah oleh sel khamir dalam jalur glikolisis, sehingga membantu efisiensi kinerja metabolisme sel khamir selama fermentasi. Kelebihan HFS pada rasa yang lebih manis dan indeks glikemik yang lebih rendah dibandingkan sukrosa dapat menjadi alternatif jenis gula yang digunakan dalam pembuatan wine.

Beberapa penelitian mengenai pembuatan wine berbahan kelopak bunga rosela telah dilakukan seperti pada penelitian Okoro dan Casmir (2007) yang melaporkan bahwa fermentasi bunga rosela dengan penambahan buah papaya sebagai sumber gula menghasilkan wine dengan warna merah keunguan serta memiliki karakteristik yang dapat diterima sebagai red wine oleh panelis dalam uji organoleptik. Menurut Gunam et al., (2009) penggunaan HFS-55 pada pembuatan wine berbahan buah salak menghasilkan rasa, warna, aroma dan penerimaan keseluruhan yang disukai, sedangkan belum ada penelitian mengenai pembuatan red wine rosela dengan penambahan HFS-55 sebagai sumber gula, maka dari itu perlu dilakukan penelitian mengenai pengaruh penambahan HFS-55 terhadap karakteristik red wine berbahan kelopak bunga rosela.

\section{METODE PENELITIAN}

\section{Tempat dan Waktu}

Penelitian ini dilaksanakan di Laboratorium Pengolahan Pangan, Laboratorium Analisis Pangan, Laboratorium Biokimia dan Nutrisi, Fakultas Teknologi Pertanian Universitas Udayana dan Laboratorium Analitik Universitas Udayana. Waktu Pelaksanaan dimulai pada Bulan Agustus sampai dengan November 2018.

\section{Bahan dan Alat}

Bahan yang digunakan pada proses pengolahan dan analisis kimia penelitian ini adalah bahan utama yang terdiri dari kelopak bunga rosela kering (surya herbal- Malang), high fructose syrup (HFS-55) merek Rose Brand, ragi roti merek Bruggemen, natrium metabisulfit, air minum kemasan. Bahan tambahan terdiri dari natrium bikarbonat (soda kue merek kopoekopoe) dan es batu, serta bahan analisis kimia yang digunakan untuk analisis meliputi asam galat, $\mathrm{Na} 2 \mathrm{CO} 3$, metanol $85 \%$, reagen FolinCiocalteau, reagen Nelson, glukosa anhidrat, reagen arsenomolybdat, $\mathrm{NaOH} 50 \%, \mathrm{HCL} 4 \mathrm{~N}$ dan akuades.

Alat yang digunakan pada proses pengolahan adalah botol $(300 \mathrm{ml})$, panci, sulit, termometer air raksa, $\mathrm{pH}$-meter kain saring, baskom besar (stainless steel), timbangan digital (ACIS), gelas ukur (Pyrex), kompor gas, corong kaca, selang kecil, plastisin, plastik dan alumunium foil. Alat yang digunakan untuk analisis adalah timbangan analitik, stopwatch, labu ukur, tabung reaksi, rak tabung reaksi, pipet tetes, pipet volume, gelas ukur, labu destilasi, erlenmeyer, vortex, cool box, corong kaca, spatula kaca dan besi, kertas saring, destilator, Gas Chromatography (Varian Type G. C. 3300), waterbath (Memmert), dan spektrofotometer (Genesys 10S UV-Vis).

\section{Rancangan Percobaan}

Rancangan yang digunakan pada penelitian ini adalah Rancangan Acak Lengkap (RAL) yang terdiri dari 5 perlakuan, yaitu jumlah penambahan HFS-55. Perlakuan diulang sebanyak 3 kali ulangan sehingga diperoleh 15 unit percobaan.

Perlakuan penambahan HFS-55 adalah sebagai berikut : 
$\mathrm{P} 1=$ penambahan HFS-55 10\%

$\mathrm{P} 2=$ penambahan HFS $-5515 \%$

P3 = penambahan HFS-55 20\%

P4 = penambahan HFS $-5525 \%$

P5 = penambahan HFS-55 30\%

Data yang diperoleh dianalisis dengan sidik ragam, apabila perlakuan berpengaruh terhadap variabel yang diamati, maka dilakukan dengan uji Duncan (Gomez dan Gomez, 1995).

\section{Pelaksanaan Penelitian}

Pelaksanaan penelitian ini terbagi atas dua tahap dimana tahap pertama adalah pembuatan starter dan tahap kedua adalah pembuatan red wine:

\section{Pembuatan Starter}

Tahap pembuatan starter diawali dengan pencucian kelopak bunga rosela yang berwarna merah, dicuci dan ditimbang 60 gram. Kemudian ditambahkan air sampai $300 \mathrm{ml}$, dimana perbandingan rosela dan penambahan air adalah 1:5. Kemudian direbus dengan suhu $70^{\circ} \mathrm{C}$ selama 20 menit, kemudian ditambahkan HFS 16\% (v/v). Larutan sari rosela yang telah dicampurkan dengan HFS-55 didinginkan sampai suhu mencapai $30^{\circ} \mathrm{C}$ dan $\mathrm{pH}$ diatur 4 dengan ditambahkan soda kue menggunakan $\mathrm{pH}$-meter. Setelah itu, ditambahkan ragi roti merek Bruggeman sebanyak $5 \%(\mathrm{~b} / \mathrm{v})$, selanjutnya diinkubasi pada suhu kamar $\left(25-27^{\circ} \mathrm{C}\right)$ selama 24 jam. Setelah melewati masa inkubasi selanjutnya digunakan sebagai starter.

\section{Pembuatan Red Wine}

Tahap pembuatan red wine diawali dengan kelopak bunga rosela kering ditimbang sebanyak 200 gram, kemudian tambahkan air 1 liter. Kelopak bunga rosela kemudian direbus selama 20 menit dengan suhu $70^{\circ} \mathrm{C}$ dan ditambahkan natrium metabisulfit $50 \mathrm{ppm}=0,05$ gram. Sari rosela yang diperoleh kemudian disaring dengan kain saring (dipisahkan ampasnya) dan didinginkan sampai mencapai suhu $30^{\circ} \mathrm{C}$. $\mathrm{pH}$ larutan sari rosela diatur hingga 4 dengan ditambahkan soda kue menggunakan $\mathrm{pH}$ meter, kemudian menambahkan starter red wine rosela sebanyak 3\% (v/v). Sari rosela yang suhunya sudah mencapai $30^{\circ} \mathrm{C}$ dimasukan ke dalam 5 botol $(300 \mathrm{ml})$ sebanyak $200 \mathrm{ml}$ tiap botol. Masing-masing botol ditambahkan HFS-55 dengan 5 perlakuan yakni P1: 10\%, P2: 15\%, P3:
20\%, P4: 25\%, P5: 30\% (v/v) lalu diaduk hingga larut. Kemudian, botol diberikan selang pada tutup botol dan celah antara selang dan botol ditutup dengan plastisin secara rapat dan aseptis. Sari rosela difermentasi selama 14 hari pada suhu kamar. Setelah fermentasi selesai dilakukan proses penuaan selama 1 minggu, proses penuaan (aging) dilakukan dengan mendiamkan red wine yang sudah mengalami fermentasi dengan melepaskan selang plastik dari tutup botol dan menutup dengan rapat.

\section{Variabel yang Diamati}

Variabel yang diamati dalam penelitian ini adalah kadar etanol dengan gas kromatografi (AOAC, 1975), (pH) dengan pH-meter (AOAC, 1975), total padatan terlarut (TSS) dengan handrefractometer (Harijono et al., 2001), total gula reduksi dengan metode Nelson Somogyi (Sudarmaji et al., 1984), total fenol dengan metode Folin-Ciocalteu (Garcia et al., 2007), kadar metanol dengan gas kromatografi (AOAC, 1975), dan penilaian sensoris yang meliputi uji kesukaan terhadap warna, aroma, rasa, dan penerimaan keseluruhan (Soekarto, 1985)

\section{HASIL DAN PEMBAHASAN}

Hasil analisis terhadap variabel uji kadar etanol dan $\mathrm{pH}$ pada red wine rosela dapat dilihat pada Tabel 1 dan terhadap total padatan terlarut, gula reduksi dan total fenol dapat dilihat pada Tabel 2.

\section{Kadar Etanol}

Hasil sidik ragam menunjukkan bahwa perlakuan penambahan HFS-55 berpengaruh sangat nyata $(\mathrm{P}<0,01)$ terhadap kadar etanol red wine rosela. Rata-rata kadar etanol red wine rosela dapat dilihat pada Tabel 1. Kadar etanol tertinggi diperoleh pada perlakuan penambahan HFS-55 $25 \%$ (P4) yaitu $10,65 \%$ dan terendah diperoleh pada perlakuan penambahan HFS-55 (P1) 10\% yaitu $8,11 \%$. Hal ini menunjukkan bahwa penambahan HFS-55 pada pembuatan red wine rosela berpengaruh pada produktifitas etanol. Etanol yang diproduksi berasal dari hasil metabolit sekunder sel khamir melalui jalur Embden-Meyerhorf-Parnas Pathways (Ristika, 2016). 
Table 1 menunjukkan bahwa kadar etanol meningkat sampai pada perlakuan penambahan HFS-55 25\% (P4) namun mengalami penurunan pada penambahan HFS-55 30\% (P5) yang berbeda tidak nyata dengan perlakuan penambahan HFS-55 20\% (P3). Hal ini disebabkan oleh karena khamir yang digunakan mempunyai kapasitas produksi alkohol paling tinggi pada konsentrasi optimum tertentu. Konsentrasi gula optimum pada proses fermentasi oleh khamir adalah 28\% dan konsentrasi gula yang berlebih dapat menghambat aktivitas khamir (Sa'id, 1987). Hal tersebut terjadi karena adanya pengaruh akumulasi gula yang menyebabkan dinding sel rusak karena perbedaan tekanan osmotik yang tinggi dalam dinding sel khamir, sehingga ketahanan terhadap dinding sel menurun. Gugus hidrofobik etanol akan berikatan dengan protein pembawa untuk berpenetrasi menembul lapisan fosfolipid membran sel, maka larutan gula mampu menembus dinding sel (Ingram dan Vreeland, 1980).

Kadar etanol yang dihasilkan pada penelitian red wine rosela ini berkisar $8,11 \%$ sampai dengan $10,65 \%$, hal ini menunjukkan bahwa mutu red wine yang dihasilkan sesuai dengan persyaratan dalam SNI: (01-4018-1996) yaitu $8-20 \% \mathrm{v} / \mathrm{v}$.

\section{pH}

Hasil sidik ragam menunjukan bahwa perlakuan penambahan HFS-55 berpengaruh nyata $(\mathrm{P}<0,05)$ terhadap $\mathrm{pH}$ red wine rosela. Ratarata nilai $\mathrm{pH}$ red wine rosela pada masing-masing perlakuan dapat dilihat pada Tabel 1. Nilai $\mathrm{pH}$ red wine rosela tertinggi diperoleh pada penambahan HFS-55 25\% (P4) yaitu 3,60 dan terendah pada penambahan HFS-55 10\% (P1) yaitu 3,43. Hasil penelitian menunjukkan bahwa nilai $\mathrm{pH}$ meningkat sampai perlakuan penambahan HFS-55 $25 \%$ (P4), dan menurun pada perlakuan penambahan HFS-55 30\% (P5) yang berbeda tidak nyata dengan penambahan HFS-55 20\% (P3). Hal ini disebabkan oleh gula yang ditambahkan dalam sari rosela bertujuan untuk memacu aktivitas khamir sehingga khamir akan menghasilkan alkohol lebih tinggi maka khamir pembentuk asam akan terhambat pertumbuhannya dan produksi asam akan rendah sehingga $\mathrm{pH}$ pada red wine rosela akan meningkat.

\section{Total Padatan Terlarut (TSS)}

Hasil sidik ragam menunjukkan bahwa penambahan HFS-55 berpengaruh sangat nyata $(\mathrm{P}<0,01)$ terhadap total padatan terlarutred wine rosela. Rata-rata nilai total padatan terlarut red wine rosela dapat dilihat pada Tabel 2. Nilai total padatan terlarut tertinggi diperoleh pada penambahan HFS-55 30\% yaitu 11,27\% Brix dan terendah pada penambahan HFS-10\% yaitu 8,03\% Brix. Nilai Brix akan semakin tinggi saat kadar gula meningkat. Sebagian besar perubahan total padatan terlarut pada minuman ringan adalah gula, sehingga adanya perubahan total gula menyebabkan perubahan total padatan terlarut. Zat yang termasuk dalam total padatan terlarut yaitu karbohidrat, lemak, protein, dan serat. Total padatan terlarut sebagian besar terdiri dari gula. Sekitar 85\% dari TPT adalah gula (Yusuf, 2002).

Tabel 1. Nilai rata-rata kadar etanol dan nilai $\mathrm{pH}$ red wine rosela

\begin{tabular}{ccc}
\hline Penambahan HFS-55 & Kadar Etanol $(\%, \mathbf{v} / \mathbf{v})$ & $\mathrm{pH}$ \\
\hline P1 $(10 \%)$ & $8,11 \pm 0,06 \mathrm{c}$ & $3,43 \pm 0,05 \mathrm{~b}$ \\
P2 $(15 \%)$ & $8,30 \pm 0,12 \mathrm{c}$ & $3,47 \pm 0,05 \mathrm{~b}$ \\
P3 $(20 \%)$ & $9,66 \pm 0,32 \mathrm{~b}$ & $3,53 \pm 0,05 \mathrm{ab}$ \\
P4 (25\%) & $10,65 \pm 0,10 \mathrm{a}$ & $3,60 \pm 0,10 \mathrm{a}$ \\
P5 (30\%) & $9,57 \pm 0,18 \mathrm{~b}$ & $3,53 \pm 0,05 \mathrm{ab}$ \\
\hline
\end{tabular}

Keterangan: Huruf yang sama di belakang nilai rata-rata pada kolom yang sama menunjukkan perlakuan berbeda tidak nyata $(\mathrm{P}>0,05)$. 
Semakin meningkatnya penambahan HFS-55 menyebabkan nilai total padatan terlarut tinggi. Menurut Simanjuntak et al., (2017) penambahan gula menghasilkan nilai total padatan terlarut yang semakin tinggi, karena gula (sukrosa) tersusun atas glukosa dan fruktosa dan sangat mudah larut di dalam air, sehingga semakin banyak kandungan fruktosa dalam bahan maka semakin banyak total padatan dalam larutan tersebut. Nilai total padatan larut yang terkandung dalam red wine rosela berasal dari HFS-55 yang memiliki kadar total padatan berkisar 76,5 77,5\% Brix (SNI 01-2985-1992).

\section{Total Gula Reduksi}

Hasil sidik ragam menunjukkan bahwa penambahan HFS-55 berpengaruh sangat nyata $(\mathrm{P}<0,01)$ terhadap total gula reduksi red wine rosela. Rata-rata nilai total gula reduksi red wine rosela dapat dilihat pada Tabel 2. Nilai total gula reduksi diperoleh dari perlakuan penambahan HFS-55 30\% (P5) yaitu sebesar $11,65 \%$ dan terendah diperoleh dari perlakuan penambahan HFS-55 10\% (P1) yaitu sebesar 6,97\%. Semakin meningkatnya penambahan HFS-55 maka terjadi peningkatan nilai total gula reduksi.

Hal ini terjadi karena penambahan kandungan fruktosa dan glukosa dalam red wine rosela sebagai bahan substrat untuk metabolit sel khamir yang termasuk dalam gula pereduksi. Beberapa contoh gula yang termasuk gula reduksi adalah glukosa, manosa, fruktosa, laktosa, maltosa, yang merupakan gula monosakarida yang dapat mereduksi suatu senyawa sehingga tergolong gula pereduksi (Lohenapessy et al., 2017). Hasil penelitian ini menunjukan semakin bertambahnya jumlah penambahan HFS-55 nilai total gula reduksi juga bertambah.

\section{Total Fenol}

Hasil sidik ragam menunjukkan bahwa penambahan HFS-55 berpengaruh tidak nyata $(\mathrm{P}>0,05)$ terhadap total fenol red wine rosela. Rata-rata total fenol red wine rosela dapat dilihat pada Tabel 2. Senyawa fenolik yang terkandung dalam red wine rosela ini berasal dari bahan baku yang digunakan yaitu kelopak bunga rosela yang mengandung senyawa fenol antosianin.

\section{Kadar Metanol}

Pada hasil analisis dengan gas kromatografi tidak terdeteksi adanya metanol pada red wine rosela untuk semua perlakuan. Kadar metanol pada wine sangat dibatasi jumlahnya bahkan diharapkan tidak ada karena zat ini bersifat racun bagi tubuh terutama pada saraf (Riyadi, 2006). Kadar metanol red wine rosela adalah negatif, hal ini berarti telah memenuhi syarat yang ditetapkan dalam SNI 014018-1996, dimana kandungan metanol pada wine memiliki batas maksimal $0,1 \%(\mathrm{v} / \mathrm{v})$ terhadap alkohol absolut.

Tabel 2. Nilai rata-rata total padatan terlarut, total gula reduksi dan total fenol red wine rosela

\begin{tabular}{crcc}
\hline Penambahan HFS-55 & TSS $(\%$ Brix $)$ & Total Gula Reduksi $\left(\%,{ }^{\mathbf{v}} / \mathbf{v}\right)$ & Total Fenol $(\mathrm{mg} / \mathrm{ml})$ \\
\hline P1 $(10 \%)$ & $8,03 \pm 0,15 \mathrm{~d}$ & $6,97 \pm 0,55 \mathrm{c}$ & $2,60 \pm 0,41 \mathrm{a}$ \\
P2 $(15 \%)$ & $8,27 \pm 0,25 \mathrm{~d}$ & $7,66 \pm 0,46 \mathrm{c}$ & $2,81 \pm 0,41 \mathrm{a}$ \\
P3 $(20 \%)$ & $9,53 \pm 0,15 \mathrm{c}$ & $9,08 \pm 0,50 \mathrm{~b}$ & $3,01 \pm 0,25 \mathrm{a}$ \\
P4 $(25 \%)$ & $10,10 \pm 0,36 \mathrm{~b}$ & $10,37 \pm 1,14 \mathrm{ab}$ & $3,08 \pm 0,28 \mathrm{a}$ \\
P5 (30\%) & $11,27 \pm 0,47 \mathrm{a}$ & $11,65 \pm 0,90 \mathrm{a}$ & $3,33 \pm 0,23 \mathrm{a}$ \\
\hline
\end{tabular}

Keterangan: Huruf yang sama di belakang nilai rata-rata pada kolom yang sama menunjukkan perlakuan berbeda tidak nyata $(\mathrm{P}>0,05)$.

\section{Sifat Sensoris}

Evaluasi sensoris red wine rosela dilakukan dengan uji hedonik terhadap warna, aroma, rasa dan penerimaan keseluruhan yang dapat dilihat pada Tabel 3 .

\section{Warna}

Hasil sidik ragam menunjukkan bahwa penambahan HFS-55 berpengaruh tidak nyata $(\mathrm{P}>0,05)$ terhadap uji hedonik warna red wine rosela. Tabel 2 menunjukkan bahwa nilai rata-rata uji hedonik warna red wine rosela berkisar antara 3,53 (biasa) sampai dengan 4,13 (agak suka). Menurut Winarno (1997), secara visual faktor warna tampil lebih dahulu dan terkadang sangat menentukan sebelum faktor lain dipertimbangkan 


\section{Aroma}

Hasil sidik ragam menunjukkan bahwa penambahan HFS-55 berpengaruh nyata $(\mathrm{P}<0,05)$ terhadap uji hedonik aroma red wine rosela. Tabel 2 menunjukkan bahwa nilai rata-rata uji hedonik aroma red wine rosela berkisar antara 2,87 (agak tidak suka) sampai dengan 4,27 (agak suka), dimana perlakuan penambahan HFS-55 25\% (P4) adalah yang paling disukai panelis. Aroma red wine rosela ditimbulkan oleh senyawa-senyawa volatil penyusun aroma antara lain alkohol, asam, ester, aldehid, keton, terpen dan lakton. Senyawasenyawa tersebut dihasilkan oleh khamir dalam memperoduksi alkohol (Lohenapessy et al., 2017). Aroma merupakan ciri lain yang penting dalam menilai tingkat penerimaan konsumen terhadap suatu produk. Menurut Winarno (1997), umumnya konsumen akan menyukai bahan pangan jika mempunyai aroma khas yang tidak menyimpang dari aroma normal.

\section{Rasa}

Hasil sidik ragam menunjukkan bahwa penambahan HFS-55 berpengaruh sangat nyata $(\mathrm{P}<0,01)$ terhadap uji hedonik rasa red wine rosela. Tabel 3 menunjukkan bahwa nilai rata-rata kesukaan panelis terhadap rasa red wine rosela antara 2,47 (agak tidak suka) sampai dengan 4,60 (agak suka). Rasa yang terdapat pada red wine berasal dari gula reduksi yang tersisa dan kadar alkohol yang terkandung dalam red wine rosela. Menurut Meilgaard et al., (1999), rasa dapat didefinikan sebagai karakteristik sensori yang diterima oleh indera pengecap manusia ketika makanan atau minuman dikonsumsi.

\section{Penerimaan Keseluruhan}

Hasil sidik ragam menunjukkan bahwa penambahan HFS-55 berpengaruh sangat nyata $(\mathrm{P}<0,01)$ terhadap penerimaan keseluruhan red wine rosela. Nilai rata-rata penerimaan keseluruhan yang diberikan panelis terhadap red wine rosela berdasarkan Tabel 3 adalah berkisar antara 3,07-4,33 dengan kriteria biasa sampai dengan agak suka. Nilai rata-rata kesukaan keseluruhan tersebut menunjukkan bahwa red wine rosela dapat diterima dengan cukup baik oleh panelis.

Penilaian panelis terhadap penerimaan keseluruhan red wine rosela pada penambahan HFS-55 25\% (P4) mendapatkan nilai tertinggi dari semua perlakuan. Hal ini berhubungan erat dengan penerimaan panelis terhadap warna, aroma dan terutama rasa red wine rosela yang dihasilkan. Semakin tinggi penilaian panelis terhadap warna, aroma dan rasa maka semakin tinggi pula penilaian panelis terhadap penerimaan keseluruhan red wine rosela.

Tabel 3. Nilai rata-rata uji hedonik warna, aroma, rasa, dan penerimaan keseluruhan red wine rosela.

\begin{tabular}{ccccc}
\hline Penambahan HFS-55 & Warna & Aroma & Rasa & $\begin{array}{c}\text { Penerimaan } \\
\text { Keseluruhan }\end{array}$ \\
\hline P1 (10\%) & $4,13 \pm 0,10 \mathrm{a}$ & $2,87 \pm 1,06 \mathrm{c}$ & $2,47 \pm 1,06 \mathrm{c}$ & $3,07 \pm 1,28 \mathrm{c}$ \\
P2 (15\%) & $4,07 \pm 0,89 \mathrm{a}$ & $3,13 \pm 0,10 \mathrm{bc}$ & $2,87 \pm 1,06 \mathrm{c}$ & $3,20 \pm 1,01 \mathrm{c}$ \\
P3 (20\%) & $3,80 \pm 1,15 \mathrm{a}$ & $3,47 \pm 1,06 \mathrm{bc}$ & $3,73 \pm 0,80 \mathrm{~b}$ & $3,60 \pm 0,51 \mathrm{bc}$ \\
P4 (25\%) & $3,53 \pm 1,06 \mathrm{a}$ & $4,27 \pm 0,80 \mathrm{a}$ & $4,60 \pm 1,06 \mathrm{a}$ & $4,33 \pm 1,05 \mathrm{a}$ \\
P5 (30\%) & $3,53 \pm 1,06 \mathrm{a}$ & $3,80 \pm 0,94 \mathrm{ab}$ & $4,20 \pm 1,08 \mathrm{ab}$ & $4,13 \pm 0,64 \mathrm{ab}$ \\
\hline
\end{tabular}

Keterangan: Nilai rata-rata yang diikuti oleh huruf yang berbeda pada kolom yang sama menunjukkan berbeda nyata pada Uji Duncan $(\alpha=0,05)$. Kriteria hedonik: 1 (tidak suka); 2 (agak tidak suka); 3 (biasa); 4 (agak suka); 5 (suka).

\section{KESIMPULAN DAN SARAN}

\section{Kesimpulan}

Berdasarkan hasil penelitian dapat

disimpulkan sebagai berikut:

1. Penambahan HFS-55 berpengaruh terhadap kadar etanol, $\mathrm{pH}$, total padatan terlarut, total gula reduksi, aroma, rasa, penerimaan keseluruhan serta tidak berpengaruh terhadap total fenol, kadar metanol dan warna red wine rosela

2. Penambahan HFS-55 25\% (P4) merupakan perlakuan terbaik yang menghasilkan red wine rosela dengan tingkat kesukaan panelis tertinggi yaitu warna biasa, aroma agak suka, rasa agak suka, penerimaan keseluruhan agak 
suka, kadar etanol 10,65\%, kadar pH 3,6, total padatan terlarut $10,10 \%$ Brix, total gula reduksi $10,37 \%$, total fenol $3,08 \mathrm{mg} / \mathrm{ml}$ dan total metanol yang negatif.

\section{Saran}

Adapun saran yang dapat diberikan yaitu dalam pengolahan red wine rosela disarankan untuk menggunakan kadar HFS-55 25\% (v/v) dan melakukan proses penuaan lebih lama agar menciptakan sifat sensoris red wine rosela lebih baik.

\section{DAFTAR PUSTAKA}

Alobo A.P. dan S.U. Affonry. 2009. Characteristics of coloured wine produced from roselle (Hibiscus sabdariffa) calyx extract. Department of Food Science and Technology. Journal of Institute of brewing: 115(2):91-94

Azizah, N., A. N. Ba'ari, dan S. Mulyani. 2012. Pengaruh lama fermentasi terhadap kadar alkohol, $\mathrm{pH}$, dan produksi gas pada proses fermentasi bioetanol dari whey dengan subsitusi kulit nanas. Jurnal Aplikasi Teknologi Pangan: 1(20):11-15

AOAC. 1975. Methode of The Association of Official Analytical. Washington D.C.

Arroyo, L., F. Noe, Orlic, Sandi, Querol dan E. Barrio. 2009. Effect of temperature, $\mathrm{pH}$ and sugar concertration on the growth parameters of Saccharomyces cerevisiae, S. kudriavaevii and their iterspesific hybrid. International Journal of Food Microbiology 131(7):120-127

Gomez, K.A, dan A.A. Gomez. 1995. Prosedur Statistik untuk Penelitian Pertanian. Edisi Ke-2. Alih bahasa: Endang Sjamsudin dan Justika S. Baharsjah. Univeristas Indonesia (UI-Press), Jakarta.

Gunam, I.B.W., L.P. Wrasiati dan S.Wito. 2009. Pengaruh Jenis dan Jumlah Penambahan Gula pada Karakteristik Wine Salak. Universitas Udayana. Jurnal Agrotekno: 1(1):12-19
Daryanto. 2008. Rosela Merah Berkhasiat. http://www.agrina-online.com (Diakses: 20 November 2018)

Garcia, C.A., G. Gavino, M.B. Mosqueda, P. Hevia, dan V.C. Gavino. 2007. Correlation of tocopherol, tokotrienol, $\gamma$ oryzanol and total polyphenol content in rice bran with different antioxidant capacity assays. Journal Food Chem: 102(28):12281232.DOI10.1016/j.foodchem.2006.07.0 12

Grainger, K. dan T. Hazel. 2005. Wine Production: Vine to Bottle. Blacwell Publishing Ltd., U.K.

Handoyo, Y. 2007. Rahasia Wine. Gramedia Pustaka Umum, Jakarta

Harijono, K. Joni, M. Setyo dan Ani. 2001. Pengaruh kadar karaginan dan total padatan terlarut sari buah apel muda terhadap aspek kualitas permen jelly. Jurnal Teknologi Pertanian: 2(2):110116

Ingram, L.O. dan N. S. Vreeland. 1980. Differential effect of ethanol and hexanol on the Escherichia coli cell envelope. Journal of Bacteriology 2 (144): 481-488.

Jaya, S.S. 2015. Kajian Mutu Fisikokimia dan Sensori Es Lilin Markisa dengan Konsentrasi Sari Bengkuang dan Jenis Penstabil Yang Berbeda. Laporan Praktek Kuliah Lapangan. Tidak dipublikasikan Universitas Sumatera Utara, Medan

Judoamidjojo, M., A.A. Darwis, dan E.G. Sa'id. 1992. Teknologi Fermentasi Edisi 1. Rajawali Press, Jakarta

Mardhiah, A.L., dan A. Sulaeman. 2010. Ektraksi kulit batang rosella (Hibiscus sabdariffa L.) sebagai pewarna merah alami. Jurnal Pertanian 1(2):40-48

Maryani, H. dan L. Kristiana. 2005. Khasiat dan Manfaat Rosela. Agromedia Pustaka, Jakarta 
Meilgaard, M., G.V. Civille, dan B.T. Carr. 1999. Sensory Evaluation Technique. CRC Press, New York

Odilora, C. A., Ozabor, C. W., Akahomhen, O. and Azi, M. C., Dye from Hibiscus sabdariffa: An investigation into its use as a colourant for some Nigerian foods. Proceedings of the 32nd Annual Conference of Nutrition Society of Nigeria, Ekpoma, 2001, pp. 40-43

Okoro dan E. Casmir. 2007. Production of red wine from roselle and pawpaw using palmwine yeast. Yaba College of Technology. Nigerian Food Journal: 25(2):158-164

Ristika, C.W. 2016. Produksi Bioetanol dari Nira Aren (Arenga pinnata M.) oleh Dry Yeast Saccharomyces cerevisiae. Skripsi. Tidak dipublikasikan. Institute Pertanian Bogor, Bogor

Sa'id, E.G. 1987. Bioindustri. PAU. Penerbit PT. Mediyatama Sarana Perkasa, Jakarta

SNI 01-4019-1996. Minuman Anggur. SK: 143/KEP/BSN/6/2013.

http://sisni.bsn.go.id/index.php/sni_main /sni/detail_sni/4405 (Diakses: 25 Maret 2018).

Soekarto, S.T. 1985. Penelitian Organoleptik Untuk Industri Pangan dan Hasil Pertanian. Bharata Karya Aksara, Jakarta

Steel, R.G.D dan J.H. Torrie. 1993. Prinsip dan Prosedur Statistika Suatu Pendekatan Biometrik. Penerjemah B. Sumantri. PT. Gramedia Pustaka, Jakarta

Sudarmadji, S., B. Haryono dan Suhardi. 1997. Prosedur analisa untuk bahan makanan dan pertanian. Liberty, Yogyakarta.

Supriatna, J. 2008. Melestarikan Alam Indonesia. Yayasan Obor Indonesia, Jakarta.

Winarno, F.G. 1997. Kimia Pangan dan Gizi. PT Gramedia Pustaka Utama, Jakarta.

Yusuf, R.R., 2002. Formulasi, Karakteristik Kimia, dan Uji Aktivitas Antioksidan Produk Minuman Fungsional Tradisional Sari Jahe (Zingeber officinale Rose) dan Sari Sereh Dapur (Cymbopogon flexuosus). $\quad$ Skripsi. $\quad$ Tidak dipublikasikan. Fakultas Teknologi Pertanian. Bogor: Institut Pertanian Bogor. 
